\title{
Millenarist vaccination and the mediascape of Mexican politics
}

\author{
Ricardo F. Macip ${ }^{1}$ iD
}

Published online: 2 October 2021

(c) The Author(s), under exclusive licence to Springer Nature B.V. 2021

\begin{abstract}
About Christmas Day 2020, the Mexican Federal Government launched a media campaign against COVID-19 ${ }^{1}$ under the guise of vaccines. Contrasting the insignificant sample of (3000) Pfizer BioNTech doses sent by the US President Trump with the spectacle made by the highest Mexican authorities (Foreign Relations and Health Ministries) and the timing, it resounded loud and clear. It was a political campaign of make-believe. Even if the statements changed over time (from Mexico being the first Latin American country with access to the vaccines, its place among the "top ten" countries worldwide carrying out vaccination campaigns, the number of doses applied and people covered, or how successful the plans were), given that under basic scrutiny each one was proven to be an exaggeration, the main aim was consistent. People ought to be misled into believing that the pandemic was dealt with and "tamed" diligently and in a timely manner. If so, in 6 months it would be over and the midterm election would therefore be a momentous day. The first half of 2021 was prodigious in the saturation of nonsense regarding the political, mediatic, electoral, and vaccination campaigns and its farcical character is their most important element.
\end{abstract}

Classical elements of the anthropological literature such as "Millenarist Cargo Cults" (Worsley 1957) or "The Gift" (Mauss 2016) were mixed in a "Mediascape" (Appadurai 1996) of the "Society of Spectacle" (Debord 1995, 1998) for everyone to see and enjoy. On the one hand, they made evident (one more time) the relation of the Mexican State Formation with the outside world, as a wide array of vaccines were imported from different power blocs. On the other hand, it asserted the forms of relations demanded by the presidential authority from its nominal citizenry. In this piece I will argue an interpretation on how by embedding the vaccination effort with media and electoral campaigns the political goal of make-believe succeeded,

\footnotetext{
1 AP News, December 24, 2020

https://apnews.com/article/mexico-coronavirus-pandemic-coronavirus-vaccine-mexico-city-16105 a31023e7ff1cdb7893b452e2906

Ricardo F. Macip

rfmacip@gmail.com

1 Benemérita Universidad Autónoma de Puebla, Puebla, Mexico
} 
persuading enough people living in Mexico that the pandemic was behind by the electoral deadline of June 6, 2021.

\section{Considerations}

The first consideration and paradox is that everything was bet on the vaccine regardless of the fact that all of them were to be imported. Mexico is a relevant manufacturing center in North America with links to the Asia-Pacific and European regions, which has renounced production of most things. This is a central feature of NAFTA, taken as a historical period, cultural horizon, specific form of integration to the outside world, and internal structuring of labor markets and industries. To rephrase a provocation among Latin Americanists (Roseberry 1989: 80), Mexico has beeneffectively and willingly-Puerto-Ricanized through NAFTA. As such, the possible solutions for the pandemic ought to come from abroad too. The most important aspect of the "Stay at Home" approach (in place since mid-March of 2020) was the trio of squalid tracing of contagions, barely any coordinated efforts for isolating sick patients and no recognizable aim at containment. Xímenez-Fyvie (2021) has led the documentation and critique against the COVID Czar Hugo López Gatell comparing and contrasting what has been done elsewhere and pointing out how the shortcomings have not been based on medical knowledge but political calculation. It is not clear what could have realistically been done as everything is presented as the only possible reaction to the arrival of a foreign virus, without examining the existing capabilities, yet the facts on the ground show that most populations were left to their own devices (Hernández Bringas 2020). As Summer and Fall of 2020 unfolded and the death toll mounted, it became clear that until the vaccines were available very little could be done. The only certainty was that the federal government was making deals with foreign laboratories and governments while planning for being the sole importer and administrator of the vaccines. An aura of hope and magic was placed on them, making it the source of many unfounded properties. For each alleged study published abroad, there was a multiplication of local versions degrading them as dangerous concoctions or exalting one as the silver bullet. Once emergency approvals started happening in China, Russia, and the NATO states, speculation about when each vaccine would arrive was rampant. There was no disagreement on the fact that the importation of different vaccines would be the scenario. After all that is the structure of the internal market in the dependent underdeveloped society (Cardoso and Faletto 1979) everybody in Mexico is aware we live in. The specificity of the speculation was on how the vaccination campaign was to be organized.

It must be stated that the numbers of estimated contagions and recorded deaths were announced daily in a press conference held by the COVID Czar and his staff. The official figures were a source of debate and fascination because it was clear from early on that there was a mediatic effort to under register them to the limited and sanctioned numbers of the Ministry of Health. In contrast, the National Institute of Statistics and Geography (INEGI) counted those people who did not die in public hospitals or were not issued a death certificate stating it was COVID signed by a medical professional, but are almost certain through complex calculations. The 
discrepancy between one and the other was quite substantial but whereas one was actualized daily, the other lagged months behind (Palacio-Mejía et al. 2021). In between, many other projections using data regarding excess deaths added uncertainty to the debate. Within the same government, the discrepancy by mid-June was 230,000 deaths recognized by the Ministry of Health (which acknowledged they were partial) and 350,000 deaths by the Ministry of Interior using the official sources (from the aforementioned INEGI) and those were not the extreme estimates considered by different researcher centers/groups. ${ }^{2}$ The effect was that informed people knew from early on that the situation was worse than the official numbers showed, but it was not clear to which extent, much less what could be done. During the fall of 2020 and in between the pronunciation of 20,000 and 50,000 official deaths, the statistic became a specter foretelling a grimmer picture. With the onset of winter, impotence and fear combined with the relaxation of self-imposed restrictions for the ritual calendar resulted in the greatest suffering within the pandemic at that point (well over 30,000 deaths in January alone ${ }^{3}$ ).

Yet, by the Christmas season (lasting from December 12 to January 6 in Mexico) most people were still unaware of how bad the consequences of mismanaging the pandemic would be and therefore the arrival of the Pfizer's sample launched a Presidential Cargo Cult. One by one the arrivals of other loads of vaccines were announced and celebrated by the press in quite symbolic terms-by symbolic I mean that the numbers were too small for the size of the Mexican Population and the schemes to administer it. Also, the Chancellor (Marcelo Ebrard) took it as a priority not only to make the deals with the powers that donated, sold, or conducted medical research with Mexican populations in exchange for vaccines as a surrogate of the presidential figure. This would be quite obvious for international dealings but the point is that it was made intelligible to Mexican audiences as a personal and highly ritualistic practice. The Chancellor went out of his way to pretend he knew what he was doing (regarding refrigeration and logistics, let alone complex biochemistry, epidemiology, and virology) each time a plane arrived in the early months giving a press briefing, underlining that he was fulfilling the presidential wish of bringing cures and health to citizens (turned into subjects). If the COVID Czar was harassed by the press and a growing number of professionals challenged his data and mismanagement of the pandemic, the Chancellor held his role of miraculous cargo cult ritual specialist producing magic powers from the sky.

\footnotetext{
24 Horas, June 16, 2021

https://www.24-horas.mx/2021/06/16/mueren-por-pandemia-mas-de-348-mil-personas-en-mexico/

${ }^{3}$ El Economista, January 31, 2021

https://www.eleconomista.com.mx/politica/Enero-de-2021-rompio-todos-los-records-Mexico-suma32729-muertes-por-Covid-19-en-un-solo-mes-20210131-0029.html
} 


\section{Braiding the campaigns}

Once the vaccines started arriving to the country, the effort to administer them got braided with the impending electoral campaign for the midterm, changing the lower chamber and almost half the governorships in the states and a lot of local governments at municipal levels. Heralded as the "biggest election in Mexican history" given how many electors would vote ${ }^{4}$ its relevance relied on the possibility that President López Obrador would lose the considerable majority he held in Congress. All the other positions were relevant too, but the fight for Congress was substantial enough to force a coalition of parties against him staging it as a referendum to his mandate. As such it dominated the media for almost a year in parallel to the pandemic. And it was the mediatic campaign which became the main force of what came to be simply invoked as "the campaign(s)." Social media, newspapers, networks in radio, television, streaming, and everything in cyberspace conflated and subsumed them into a nebulose but there was no doubt that they were ordered and articulated from the mediatic to the electoral and finally to the vaccination in a single political process. Its political nature escaped no one and there was actually very little effort to hide it or pretend they were separated. That does not mean everybody agreed on what politics was or to what extent contagion and death would be politicized.

Over the next 6 months, the vaccination campaign unfolded irregularly as the plans to immunize the target populations were highly centralized by the duo made by the President and his COVID Czar (aided by "technical advising group"). The campaign was supposedly operating under the pretense that it would follow scientific and medical considerations held in common by health specialists, demographers, and collegiate groups of relevant professionals. However, it did not. The decisions were shared in a mutually deceptive cycle, in which the President acted as if he was following the advice of his most trusted epidemiologist, who in turn applied political criteria following the Presidential decisions. Critiques and dissent were aired constantly in all forms of media and dismissed as political attacks and propaganda. The most relevant disagreement came from the official in charge of vaccination campaigns for infants and youth who was sidelined and renounced her position. ${ }^{5}$ Even though she said it was due to "stress, ${ }^{6 "}$ almost everybody understood there were no other criteria than political calculation.

\footnotetext{
${ }^{4}$ Forbes, September 7, 2020

https://www.forbes.com.mx/politica-comienza-el-proceso-electoral-2021-el-mas-grande-de-la-historiade-mexico/

5 Expansión, January 17, 2020

https://politica.expansion.mx/mexico/2021/01/17/la-encargada-del-plan-de-vacunacion-contra-covid19-deja-el-cargo

6 Animal Político, January 17, 2021

https://www.animalpolitico.com/2021/01/renuncia-encargada-vacunacion-mexico-motivos-personalessalud/
} 
The first group to be vaccinated, as in other parts of the world, was health professionals. ${ }^{7}$ Images of nurses getting the first shot were reproduced in most countries as they launched their corresponding campaigns, but in Mexico this would prove misleading. No one doubted medical personnel in hospitals were the most exposed, yet not all of them would benefit as we would see. Following the alleged "essential" element in the "fight" against the "invading virus" were the poorest segments of the population in 300 immiserated and remote municipalities of the country. ${ }^{8}$ Of course, due to the alarming numbers of infected people and rates of contagion in big cities and their metropolitan areas, given the mobility of working people (especially in the informal sector), this only made sense because there were few available doses to mount a credible vaccination campaign. Not so to the mediatic and political. The oldest, poorest, and most marginalized, against those perceived as wealthy and foreign, ${ }^{9}$ were the first to receive the vaccine, just as in the Biblical parables the President is fond of using in his daily morning homily (Bartra 2021: 83). It is he in the position of sovereign — defining and above the law (Agamben 1998)—who could decide what was just and fair. In the same tone, the population was segmented in age and territorial demarcations following state and municipal groupings. People above 60 would follow but no pattern of criteria other than those two were made evident. Needless to say that the availability of vaccines and where they were was clouded in mystery. The COVID Czar and his team would inform about arrivals secured by the Chancellor, but after that there was no way to follow where they went and under which conditions they were guarded. "National Security ${ }^{10 "}$ " was invoked as the circular reason to keep them out of public scrutiny.

When and how the vaccination campaign would happen were further complicated by the specific vaccine being used. The Chancellor made deals with the countries and corporations behind five vaccines: Pfizer-BioNTech, Sputnik V, AstraZeneca, Sinovac, and CanSino. So, even though it was easy to deduce that depending on the availability of vaccines, specific demarcations with the approximate numbers for the target population would be selected, this would be further complicated by the exceptions to each case. The most aggravating was the case of medical personnel. Only those working in public hospitals would benefit and not all. Mysteriously, different branches of the "national system of health" would decide who qualified without making their reasoning public. This provoked different mobilizations by public sector health professionals ${ }^{11}$ followed by many others by private sector nurses, dentists,

\footnotetext{
7 France24, February 2, 2021

https://www.france24.com/es/am\%C3\%A9rica-latina/20210202-vacunaci\%C3\%B3n-mexico-esperanzapolemica-logistica-distribuci\%C3\%B3n

8 Animal Político, February 14, 2021

https:/www.animalpolitico.com/2021/02/mexico-manana-vacunacion-adultos-mayores/

9 México Ahora, February 26, 2021

https://mexicoahora.com/internacional/no-se-vacuna-a-extranjeros-mexico-se-niega-a-aplicar-vacun as-a-migrantes/

10 Milenio, April 20, 2021

https://www.milenio.com/politica/organismos/inai-acuerdos-vacunas-vulnera-seguridad-nacional

11 La Jornada, March 10, 2021

https://www.jornada.com.mx/notas/2021/03/08/estados/protestan-medicos-del-imss-en-periferico-nortedemandan-vacunas/
} 
physicians, and emergency personnel. ${ }^{12}$ The reasons for discriminating among them and against some were never entirely clear for there were no valid explanations. Most people in Mexico are without health coverage (barely $41 \%$ has it, according to Puentes-Rosas et al. (2005)), and therefore, the vast majority of the impoverished population of the "informal" sector seeks private treatment. The fact that it is private by no means implies some sort of luxury. Quite the contrary, cheap dispensaries and consultation in drugstores are the de facto first line of contact for diagnosis. If anything, it was an ideological prejudice by the duo of President and Czar personas who decided to leave them out.

The differentiated assortment of vaccines was in critical shortage for the demand of a population of roughly 126 million. Administering them in an ordered way proved to be difficult as most (CanSino being the exception) require a two-dose application. So, if a population was selected in a specific demarcation to get the first of any one vaccine, the supply of the second in the specified weeks to come needed to be secured. This was an act of faith. What was common was the contingent injection of the first dose without knowing exactly when the second would be applied and if it would be the same one. The exceptions were the rule and speculation about whether counter indications to mixing different vaccines or lengthening the time in between doses set the basis for the perverse mockery in which almost everybody partook. However, that was secondary to the inevitable fetishism that surrounded each vaccine of the five that were administered. The original cargo of Pfizer and the prestige it enjoyed above all the others were compared and contrasted against it in nonsensical trolling on social media, mixing relevant information published in medical journals with deeply held prejudices of political and racist nature. Among the first was the fear or nostalgia brought by Sputnik V to those old-enough to remember the "Red Scare" of the Cold War and among the latter the enduring sinophobia. ${ }^{13}$ The Chinese vaccines were characterized as cheaper and substandard, each with its own features. Sinovac was better than nothing and everybody knew there would be more of it than Pfizer and as such was used early among those 60 years and older. CanSino was restricted for educational personnel and therefore the butt of jokes given the low esteem schoolteachers and university professors have in general and specifically because of the stigma they earned during the pandemic. Being almost the only group of workers that was both paid regularly and part of the monumental fiasco of online education during the only enforced lockdown, educators were mocked as guinea pigs of a vaccine that was taunted as little more than a placebo. AstraZeneca has its own tale of complications as it was the earliest championed by both ministries (Foreign Relations and Health) in a shoddy schema triangulating the governments of Mexico and Argentina with the Anglo-Swedish corporation and a well-known businessman (Carlos Slim) no one can seriously pretend is a philanthropist (as he

\footnotetext{
12 EFE, April 14, 2021

https://www.efe.com/efe/usa/mexico/medicos-particulares-en-mexico-exigen-recibir-la-vacuna-antic ovid/50000100-4512038

13 Milenio, May 17, 2021

https:/www.milenio.com/estados/masacre-chinos-1911-torreon-mexico-pide-perdon
} 
pretends, following the model for tax evasion accrued abroad). ${ }^{14}$ The lack of respect for one and all involved kept a shadow of risk attached to it. Pfizer remained the sole representative of the NATO arrogance and certitude, even though the Biden administration eventually sent a cargo of Janssen to secure the opening of the border. ${ }^{15}$ Not only was the gesture late, 6 months into the campaign started by a gift from his predecessor, but was sent once the elections were over, and made no effort to disguise it was self-interested (as they were to be administered to population living on the border states). It had no impact whatsoever.

Moderna remained out of reach during the political campaign and as such developed an aura of security not to be enjoyed by anyone vaccinated in the country. Of course, those who were able cross the border to the USA did so. The border states of Texas and Arizona (along with Louisiana) very early on allowed ${ }^{16}$ every adult to be vaccinated regardless of residence. Later other states did this as well. Those who dared to publicize this privilege on social media were accused of all sorts of folkloric excesses (betrayal, prostitution, and/or abjection among others), so it became a subject to keep quiet about, making any estimate of the number of people vaccinated this way contentious. Yet, what is important is not only that people had their own ideas regarding which vaccine they were fortunate enough to get, but that this was further stimulated by the governmental lie that all of them worked the same and were likely to be exchangeable. Even if most people cannot understand the scientific basis for such assertions, they knew it was a political lie. The COVID Czar ought to know better than the President but if he was not telling the truth, it was because the vaccination campaign was subordinated to political designs to be fought in media and harvested on election day.

The multiplication of stories about the vaccines and their reputations have some real lows like the practice of "saving syringes," administering less than the required dosage of Pfizer ${ }^{17}$ and a few accusations of faking the injection with ai, ${ }^{18}$ yet those were exceptions. Unevenly, capriciously, and discretionally, just a week before the election the majority of those above 60 years old had their two doses, those above 50 have begun to receive injections, and the vaccine had been promised to those above 40 years old. The message was clear: it was poorly designed and disorganized but

\footnotetext{
${ }_{14}$ Contrapeso Ciudadano August 30, 2019

https://www.contrapesociudadano.com/fortuna-de-slim-producto-de-corrupcion-criminal-asi-criticabanal-empresario-favorito-de-amlo/

15 EFE, June 15, 2021

https://www.prensalibre.com/internacional/llegan-a-mexico-1-35-millones-de-vacunas-de-janssen-queenvio-estados-unidos-para-luchar-contra-el-coronavirus/

16 USA Today, April 21, 2021

https://www.usatoday.com/story/travel/news/2021/04/21/vaccine-tourism-wealthy-latin-americans-seekcovid-shots-us/7316662002/

17 Excelsior, June 3, 2021

https://www.excelsior.com.mx/comunidad/confirman-que-hubo-aplicacion-de-7-dosis-por-frasco-devacuna-pfizer/1452504

18 El Sol de Hermosillo, April 1, 2021

https://www.elsoldehermosillo.com.mx/local/mujer-de-95-anos-recibe-aire...-en-lugar-de-vacuna-covid19-cajeme-taddei-6547901.html
} 
the federal government was delivering vaccines like everything else in a dependent society that does not produce much and therefore relies on imported goods of radically differentiated qualities. The main difference (against the "neoliberal long night") is that under President López Obrador it was not the market that sorted out who got access to which vaccine(s) but the sovereign himself. Whoever got vaccinated was lucky and up to a degree indebted to the President's will under the three rules of sacred archaic exchange: to give, to receive, and to reciprocate (Mauss 2016: 58). To what extent which groups complied on election day is still unclear and a matter of speculation but the political campaign was a resounding success.

\section{Twilight}

The plateau of deaths and contagions that followed the peak of January and its clear decrease since the middle of May started to climb up again right at the appointed date of early June. ${ }^{19}$ Regardless of the reasons for this, as all sorts of blame are traded in social media; the campaigns worked in the sense that almost everybody wanted to believe the brunt of the pandemic was in the past. Election day was a celebration of democratic normalcy breaking the record of participation for a midterm with $52.67 \%$ of the electorate voting ${ }^{20}$ but also about having survived the pandemic. The week before, the Federal Government in cahoots with most state governments modified their infamous ${ }^{21}$ "traffic light" code to declare most of the country in "green" misleading no one. By then people were just sick of all the measures and went to the streets and the polls en masse. By the middle of June ${ }^{22}$ less than $12 \%$ of the target population to be vaccinated had completed their doses. After accelerating it towards the election, the pace of vaccination has also slowed down ${ }^{23}$ and there is no need to explain why. The daily evening press conferences of the COVID Czar were also terminated on June $11,2021,{ }^{24}$ even though he made clear that the pandemic was not over. Nobody was impressed after 451 occasions of spreading halftruths, propaganda, and misinformation. The fact is that things went (almost) back to normal right when they started to get worse again.

\footnotetext{
${ }^{19}$ El País, June 25, 2021

https://elpais.com/sociedad/2020-06-25/la-epidemia-crece-sin-descanso-en-mexico.html

20 Expansión, June 8, 2021

https://politica.expansion.mx/mexico/2021/06/08/la-participacion-electoral-cierra-en-52-67-cinco-puntos-mas-que-en-2015

21 etcétera, December 12, 2020

https://www.etcetera.com.mx/sin-categoria/lopez-gatell-apaga-semaforo-color-intrascendente/

22 El País, June 13, 2021

https://elpais.com/mexico/2021-02-23/asi-avanza-la-vacunacion-contra-coronavirus-en-mexico.html

23 El Financiero, June 17, 2021

https://www.elfinanciero.com.mx/salud/2021/06/17/se-acelero-vacunacion-previo-a-elecciones-y-ahorahay-un-bajon/?fbclid=IwAR1A4oz6YFB_BNwiKOdTBcIkJ5pe4tFcrGeksYRdM_JkbL3-31eyl6KB8sU

24 Forbes, June 11, 2021

https://www.forbes.com.mx/la-ultima-conferencia-vespertina-de-lopez-gatell-en-palacio-nacional/
} 
What this tells us is that the collective unconscious or the accepted forms of dominance (Abrams 1988) in fatalism and subjugation are secondary to the great success of the campaigns. Ordinary people know that they have been lied to, that the pandemic has not been confronted but politically mismanaged for more than a year and a half, and that it will remain the same: whoever must die will do so as nothing will stop "the economy" and their "essential" sectors as defined from abroad within NAFTA. The vaccines may work but not at the insignificant proportion of the population to which they have been applied. Yet if the media and political campaigns have worked out so well, it is because enough people want to believe in them to feed the cognitive dissonance that self-deception demands. The next round of electoral spectacle is 3 years in the future and in between people will die horrible and preventable deaths, caused by COVID_even if vaccinated, as is happening ${ }^{25}$ —or other preventable ailments, let alone tragedies ${ }^{26}$ separated from armed violence. In the meanwhile, calid and willing alienation is all there is left in the millenarist mediascape of political make-believe.

Even though I run the risk to appear frivolous or disrespectful by using terms like cargo cults, gift-giving, and even mediascape, I want to underline that their use derives from their descriptive accuracy and all the seriousness inherent in their analytical potential. This is better understood if we compare how the pandemic unfolded in Brazil and the USA and how it affected presidents Bolsonaro and Trump. In contrast to how both were blamed for mismanaging the crisis and are still being accused of indifference and callousness, López Obrador was able to soften its perceived impact by braiding it with the other campaigns. Rather than effective containment or responsible scientific approaches, he used magic over the calamity undermining its relevance and his responsibility. The success is by no means in public health as, once the number of deaths is adjusted to the size of the population, Mexico has fared worse than those of the USA, Brazil, and India (while in competition for the world's worst lethality ${ }^{27}$ ). What he "aced at" was in channeling fatalism withing mediatic and political campaigns using secular and religious elements admixed within a society of spectacle (Debord 1995, 1998). The total and relative number of imported doses and their availability are and will be a matter of contention ${ }^{28}$ as there is little chance to corroborate anything authorities claim, yet the relevance is the apocryphal tale that there are enough doses to be administered due to the President's goodwill. Much like all Cash Conditioned Transfers programs and their proven potential for

\footnotetext{
25 El Universal, June 18, 2021

https://www.eluniversal.com.mx/estados/muere-dentista-que-tenia-esquema-de-vacunacion-compl eto-contra-covid-19-en-nl?fbclid=IwAR3u4MRyzdIiYkq7goIRkyP_t71d85ZqTrWA25yDeWwyIXH1CmJvKaMqXk

26 NYT, June 16, 2021

https://www.nytimes.com/es/2021/06/16/espanol/linea-12-peritaje.html

27 Mexico News Daily, January 1, 2021

https://mexiconewsdaily.com/news/coronavirus/mexico-remains-at-bottom-of-list-of-worst-countries-tobe-in-during-covid/

28 Nexos, June 21, 2021

https://datos.nexos.com.mx/como-va-el-avance-en-la-aplicacion-de-vacunas-contra-covid-19-en-mexico-corte-al-19-de-junio-de-2021/
} 
buying up political clienteles and loyalties, so have the vaccines worked out nicely. The main difference is that rather than a professional effort conducted by well-calibrated and articulated governmental bureaucracies, political parties, technocrats, and/or surrogated NGOs, it is the President who grants life over death.

The eloquence of his success reflects partially in the results of the election in which his party coalition kept the majority of the lower chamber and took 11 out of 15 state governorships. ${ }^{29}$ That is a decisive win even if not comparable to his 2018 crushing victory. However, the most resounding achievement of the campaigns was transmutation of the pandemic into yet another endemic and congenital ill of the country like violence and insecurity. COVID-19 is going to be added to the list of preventable causes of death to which everyone in the country is exposed, but seasonally ravage "the poor" (Macip 2010). The ability to depoliticize them demands a combination of magic (Coronil 1997) and "bigmanship" (Bayart 2009) using "little men" as proxies. President López Obrador has shown us all that he is a far more resourceful trickster and leader than anticipated. The pandemic did not affect him for the midterm elections, which failed to become a referendum on his administration and persona. In contrast to the monstrosity of death and destruction that demographers fight to establish and opposition politicians to blame him for, this mystification is a remarkable feat. Of course, he still has 3 years in his (not re-electable) sexenio (6 years period) and his legacy will not be affixed in political folklore or historically appreciated until years or decades to come. As the country enters another liminal space of make-believe regarding the pandemic after the midterm election, his ability to wage a reactionary Kulturkampf as "constitutive conflict" (Turner 1975: 102) remains his most enduring gift.

\section{Coda}

The most relevant development once the election was over and summer advanced was the spike in contagions and deaths produced by the Delta variant of COVID. Even though there is no agreement on how to refer to or measure the "waves" of the pandemic, as it has never quite disappeared, it became clear that the trend of growing contagion was stronger than the previous two peaks (summer 2020 and winter 2021). More important than that is the eloquence of the effect. Although more people got infected, the rate of death was lower than before, no matter how both indicators were measured. ${ }^{30}$ The daily reports on contagion surpassed in August ${ }^{31}$ those $^{2}$

\footnotetext{
${ }^{29}$ El Heraldo de Mexico, June 11, 2021

https://heraldodemexico.com.mx/elecciones/2021/6/11/mapa-electoral-de-mexico-asi-quedan-los-estad os-tras-la-eleccion-del-de-junio-305097.html

30 El Financiero, September 19, 2021

https://www.elfinanciero.com.mx/salud/2021/09/19/tercera-ola-covid-se-derrumba-en-mexico-registranueva-caida-ahora-del-26/?outputType $=$ amp\&fbclid=IwAR3wQaecwlz_eHK30MA05ogmGxHr2Pv8 vmSd9AYtzCOhTJQue_1TuuxPThI

31 El Economista August 31, 2021

https://www.eleconomista.com.mx/arteseideas/18420-personas-murieron-de-Covid-19-en-agosto-mesrecord-en-contagios-20210831-0089.html
} 
of January with lower death rates. The Delta variant was much publicized following its ravaging in India ${ }^{32}$ and therefore given a virulent and lethal persona. So, in an unplanned way the debates that ensued extended credence to the President's actions: no matter which, no matter how, the vaccines worked out reasonably well.

The vaccination campaign continued with all its mishaps and problems covering with complete doses by the end of summer almost everybody above 40 years of age who registered and followed procedure, halfway with those above 30, and starting with those of the younger cohorts. By the middle of September, the approximated covered adult population was around $28 \% .^{33}$ The most important challenge to the campaign and authority came from parents using Habeas Corpus securing inoculation for minors ${ }^{34}$ to which after enough friction would be granted if suffering a chronic disease. ${ }^{35}$ Also, Moderna got added to the mix by mid-August ${ }^{36}$ and other vaccines - including Cubans - are under review and approval. The campaign is supposed to end by October 31, 2021, and there is no clear understanding about what is going to replace it for the next year. Under the incertitude of what may be coming, minors have returned to schools ${ }^{37}$ and higher education will follow suit gradually. There is no plan to ensure containment or prevention but the simulacra of gatekeeping, measuring body temperature, administering sanitizing gel, and requesting face masks. Inside buildings and at public transportation, everything goes as before the pandemic. Over the next 6 months or so we may start to fathom what has been the toll in human lives.

Acknowledgements and methodology This piece is a follow-up to The Party is Over: Cracking Under Sana Distancia in Mexico, published in volume 44 (3) of Dialectical Anthropology. While uploading it, I accidentally erased the following note, which remains valid. "Due to the privilege to follow the Stay-atHome exortation, I did not interview or researched this piece with other means than the attentive reading of the press. The notes I use as the main references came from El Heraldo de Puebla (EHDP), a daily newspaper in the city of Puebla (Mexico). I had not enlisted them one by one but as the common thread of reliable information and collective editorial authorship. I had access to them thanks to his Director Erick Becerra. All other periodical references are properly recognized and listed in sections. I sent drafts of these pieces to Deanna Davis, Maia Becerra and Rodrigo Macip who corrected it, made suggestions and provided insights for its improvement. I thank them without sharing the responsibility which is all mine."

\footnotetext{
32 Forbes, June 23, 2021

https://www.forbes.com.mx/delta-plus-nueva-variante-coronavirus-india/

33 Statista, September 10, 2021

https://es.statista.com/estadisticas/1207749/porcentaje-vacunados-inmunizados-covid-19-mexico/

34 El País, September 9, 2021

https://elpais.com/mexico/2021-09-10/la-vacuna-contra-la-covid-para-los-ninos-en-mexico-se-consi gue-en-los-tribunales.html

35 El Universal, September 24, 2021

https://www.eluniversal.com.mx/nacion/vacunacion-covid-19-ninos-con-comorbilidades-inicia-registroel-1-de-octubre

${ }^{36}$ La Jornada, August 17, 2021

https://www.jornada.com.mx/notas/2021/08/17/politica/cofepris-aprueba-vacuna-de-moderna-tras-dosdosis-tiene-94-1-de-eficacia/

37 El Economista, August 30, 2021

https://www.eleconomista.com.mx/politica/Regreso-a-clases-CDMX-ninas-ninos-y-adolescentes-vuelv en-a-las-aulas-tras-ano-y-medio-de-estudiar-en-sus-casas-20210830-0047.html
} 


\section{References}

Abrams, Philip. 1988. Notes on the difficulty of studying the state. Journal of Historical Sociology 1 (1): 58-89.

Agamben, Giorgo. 1998. Homo sacer: Sovereign power and bare life. Stanford: Stanford University Press.

Appadurai, Arjun. 1996. Modernity at large: cultural dimensions of globalization. Minneapolis: University of Minnesota Press.

Bartra, Roger. 2021. Regreso a la Jaula: El fracaso de López Obrador. Debate, México.

Bayart, Jean Francois. 2009. The state in Africa: The politics of the belly. Cambridge: Polity Press.

Cardoso, Fernando H., and Enzo Faletto. 1979. Dependency and development in Latin America. Berkeley: University of California Press.

Coronil, Fernando. 1997. The magical state: Nature, money and modernity in Venezuela. Chicago: The University of Chicago Press.

Debord, Guy. 1995. The society of spectacle. New York: Zone Books.

Debord, Guy. 1998. Comments on the society of spectacle. New York: Verso.

Hernández Bringas, Héctor. 2020. CCOVID-19 en México: un perfil sociodemográfico Notas de Población 111:105-132.

Macip, Ricardo F. 2010. "Influencia porcina": duplicidad y estado de excepción en el brote primaveral mexicano de 2009 IN Ricardo F. Macip y Natatxa Carreras Sendra (EDS) Perversión y duplicidad: en torno a la producción de subjetividades del cuerpo político en México. ICSyH-BUAP, Puebla.

Mauss, Marcel. 2016. The gift HAU Books, Chicago.

Palacio-Mejía, Lina Sofía, et al. 2021. Estimación del exceso de mortalidad por todas las causas durante la pandemia del Covid-19 en México. Salud Pública de México 63 (2): 211-224.

Puentes-Rosas, Esteban, et al. 2005. Estimación de la población con seguro de salud en México mediante una encuesta nacional. Salud Pública de México 47 (1): 22-26.

Roseberry, William. 1989. Anthropologies and histories: Essays in culture, history and political economy. New Brunswick: Rutgers University Press.

Turner, Victor. 1975. Dramas, fields and metaphors: Symbolic action in human society. Ithaca: Cornell University Press.

Worsley, Peter. 1957. The trumpet shall sound: A study of cargo cults in Melanesia. London: Macgibbon \& Kee.

Xímenez-Fyvie, Laurie Ann. 2021. Un daño irreparable: La criminal gestión de la pandemia en México. México: Planeta.

Publisher's note Springer Nature remains neutral with regard to jurisdictional claims in published maps and institutional affiliations. 